First publ. in: European Political Science 6 (2007), 2, pp. 156-159

\title{
why is european political science so unproductive and what should be done about it: a symposium
}

\author{
gerald schneider
}

Department of Politics and Management, University of Konstanz, Box D 86, D-78457 Konstanz, Germany

E-mail: gerald.schneider@uni-konstanz.de

\begin{abstract}
The worldwide departmental ranking by Simon Hix and national performance evaluations have dramatically shown that European political science is not sufficiently competitive at the global level. This symposium analyses why this is the case and what kind of reform measures should be introduced to move beyond this dire state of affairs. The authors detail the problems in four domains - (i) funding of teaching and research; (ii) the 'market' for political science education; (iii) career development, salaries, and tenure decision-making; and (iv) the publication behaviour of European political scientists. Each contribution concludes with suggestions about how the situation could be improved.
\end{abstract}

Keywords scientific productivity; departmental rankings; specialisation

S everal evaluations, most notably Hix (2004a, b), have recently demonstrated that the scholarly productivity of European political science is well below the output of US-based scholars. To offer a dramatic illustration of this gap, the evaluation by Plümper (2003) can serve as an example. His analysis of publications indexed in ISI Web of Knowledge has shown that in the period between 1990 and 2002 authors from Harvard University produced more arti- cles in political science journals than authors from any German department and from departments in most other European countries (Plümper, 2003: 535). Eighty-five European departments as compared to ninety-seven US ones appear among the top 200 political science departments in the world ranking by Hix (2004a: 304f). As is to be expected, the European states fare differently on this list. While the United Kingdom possesses forty-eight top-200 
departments, Germany has ten and France two. Italy and Spain both appear once in the ranking, whereas Poland does not make it onto the list. Among the middle-sized and smaller European states, the Netherlands (five), Norway (three), Sweden (three) and Switzerland (three) have more than two relatively productive departments. Hungary is the only postcommunist country that appears in the list of the 200 leading departments. Admittedly, the situation looks less dramatic if we compare America and Europe in terms of overall productivity. North America accounts for slightly above 50 per cent of the output, whereas Europe as a whole accounts for more than 40 per cent. Yet, this does not compensate for the almost complete lack of European (or at least Continental European) representation at the top of the lists.

The different department rankings have led to an intensive discussion - not the least in this journal - about how productivity should be evaluated. However, the discipline has not yet devoted much time to careful analysis of the factors that have caused this continental divide in publication success. As many claim that political science is a field pioneered by US scholars, such a discrepancy might seem natural. Yet, as the intellectual history of such powerful ideas as the median voter theorem or Duverger's Law show; or as the development of the social sciences in Vienna before World War II demonstrates, the discipline has roots that are as much European as American.

In order to take a first step in the direction of the systematic study of European political science, Gerald Schneider (Konstanz) organised a roundtable at the ECPR General Conference in Budapest in September 2005. Although this event was scheduled for $6.00 \mathrm{pm}$ on what was a mercilessly hot final day of the conference, around 120 scholars attended the discussion on the state of the discipline and possible reform measures. Admit- tedly, the title of the roundtable was a provocation: 'Why is European political science so unproductive and what should be done about this?' However, as the intensive discussion among the panellists and the audience demonstrated, the roundtable struck a chord. The truly European-wide interest that was shown at the roundtable justifies, in our view, the decision of four of the panellists - Nils Petter Gleditsch (Peace Research Institute Oslo and University of Trondheim), Katharina Holzinger (Hamburg), Gerald Schneider and Bernard Steunenberg (Leiden) - to accept the invitation of the editors of EPS to develop their thoughts further. The fifth participant, Richard Bellamy (University College, London), mainly provided responses from the perspective of the ECPR. As he retired from his position as the ECPR's Academic Director in the spring of 2006, this symposium does not include an official reaction on behalf of the ECPR. Yet, no such diplomatic response seems necessary; for the contributors to this debate all address issues that touch only marginally upon the activities of the ECPR as such. In their view, most problems are at the national level although some inadequacies are also manifest with regard to the funding of research and teaching through the European Commission.

None of the contributors to this forum engages in masochistic self-flagellation or whiny lamentations that reflect solely personal frustrations. All contributors to the exchange rather believe that the problems are structural and that the situation could and should be improved. A first step in this direction is our attempt to talk about the problems of European political science in an open and sober manner. In the view of all contributors to this debate, European political science has often been too hesitant and too nationalistic. The growing collaboration across national boundaries and the increased proficiency of the discipline in 
English helps, in their view, definitively to move the self-reflection beyond the defeatist attitude that we cannot do much about this malaise. Although the extent of the problems varies across countries, most of the deficits of European political science are present in all the states in which this discipline is taught. Our analysis and recommendations are thus not aimed at one particular member state of the European Union. The general message is, however, that we should strive for a truly international labour market with incentive-based salary and promotion schemes, internationalised reviewing processes for both publication and research grants, as well as more academic mobility for students and researchers. In our view, one of the consequences of the increased cross-border competition will be the increased substantive and methodological specialisation of leading departments in research and teaching. We believe that this will ultimately make the discipline more productive and, last but not least, our teaching and research more interesting.

It is obvious that some readers might not agree with our desire that European political science become more competitive through increased specialisation. They fear that this form of globalisation or Europeanisation, to use two buzzwords, might endanger diversity within departments and lead to departmental monocultures. Although specialisation might thus make intra-departmental life more boring, this might be a small price to pay in comparison with the collective gains that we could all make in the form of deeper and more relevant research and teaching.

Another reaction to this symposium might be the conviction that increased international visibility will make us nationally more redundant. It is indeed the case that, as Steunenberg notes in his contribution, we will continue to educate our students for mainly national labour markets. For the majority of these students, the latest high-profile research on the US Congress is of lesser importance for their future professional lives than a profound knowledge of European and national institutions and decision-making processes. However, we still do not have sufficiently frequent high-level intellectual debates on how we can understand the functioning of these rules. To do so we need, as both Gleditsch and Holzinger confirm, more European-based top journals and, linked to this, more encouragement to junior and senior scholars to publish in them.

Others finally might contend that our tone is alarmist and that European political science is much more successful than global rankings of leading departments and other highly aggregated information might reveal. One participant indeed remarked that we are doing astonishingly well in light of all the frustrating constraints that we are facing. Although our gloomy analysis might thus not be fully warranted, most European-based political scientists would probably nevertheless agree with us that there is a need to improve our collective performance and that we should find ways in which we can profit from the full potential that is among us and that often enough leads to results that make us all proud.

We believe that the structural deficits that we all face in our daily work are present in four areas: funding; the organisation of political science within the European university system; individual career incentives, and, last but not least, the norms that guide us in reviewing and publishing our own research. All contributors to this symposium were invited to analyse one of these areas and to suggest realistic reforms.

The debate starts out with a discussion of several input aspects such as funding and career incentives before we move to an assessment of why the quality of 
our measurable output - publications frequently fails to reach the standards of top US departments. Since excellent teaching needs to be based on original research activities, we believe that our classroom presentations are often not as enlightening as they should be. Research and teaching thus ultimately hang together. Any politician who tries to strengthen one at the expense of the other hampers our collective endeavour, namely, to bring about the emergence of European political science as a rigorous, globally competitive field within the social sciences.

\section{References}

Hix, S. (2004a) 'A global ranking of political science departments', Political Studies Review 2(3): 293-313.

Hix, S. (2004b) 'European universities in a global ranking of political science departments', European Political Science 3(2): 5-23.

Plümper, T. (2003) 'Publikationstätigkeit und Rezeptionserfolg der deutschen Politikwissenschaft in internationalen Fachzeitschriften, 1990-2002. Eine bibliometrische Analyse der Veröffentlichungsleistung deutscher politikwissenschaftlicher Fachbereiche und Institute', Politische Vierteljahresschrift 44(4): 529-544. 